\title{
A rare cause of neutropenia: An Illusion (EDTA-induced pseudo-neutropenia)
}

\author{
${ }^{1}$ Hava Üsküdar Teke, ${ }^{2}$ Sümeyye Türk, ${ }^{3}$ Bülent Yıldız, ${ }^{4}$ Gökhan Temiz \\ ${ }^{1}$ Eskişehir Osmangazi University Faculty of Medicine, Department of Hematology \\ ${ }^{2}$ Eskişehir Osmangazi University Faculty of Medicine, Department of Internal Medicine \\ ${ }^{3}$ Eskişehir Osmangazi University Faculty of Medicine, Department of Medical Oncology \\ ${ }^{4}$ Eskişehir Osmangazi University Faculty of Medicine, Department of Nephrology \\ *email: havaus@yahoo.com
}

Sixty years old male patient was admitted to hospital for squamuos cell lung carsinom with brain metastasis. After two cure taxol and cisplatin chemotherapy and cranial radiotherapy was applied diarrhea and diminished oral intake were developed. After admission chest radiogram revealed pneumothorax and a chest tube was performed. Because of purulent chest drainage, microbiological examination was performed and Escherichia coli and Enterecoccus faecalis were identified. According to the antibiogram result imipenem, teicoplanin and ciprofloxacin was begun. During hospitalization first laboratory examinations were as follows; hemoglobin level 10,9 gr/dl white blood cell counts (WBC) 5,5x109/L, platelet counts 210x109/L, absolute neutrophil counts (ANC) 3,6x109/L, erythrocyte sedimentation rate $85 \mathrm{~mm} / \mathrm{h}$, Creactive protein $17,8 \mathrm{mg} / \mathrm{dl}$. But on the second day ANC was 0,2 x109/L. Peripheral blood smear revealed neutrophil agglutination (figure 1A, 1B) and blood count was performed with a citrate buffer tube examination for the doubt of ethylenediaminetetraacetic acid (EDTA) secondary pseudo-neutropenia. And the ANC count was 4,6 x109/L and the patient was considered as pseudo-neutropenia secondary to EDTA. Patient was died 7th day of admittion due to sepsis.

Major causes of neutropenia during hospitalization were infections and drugs. Bone marrow metastasis secondary to solid malignancy should also be considered in patients with malignancy and neutropenia. But without exclusion of pseudo-neutropenia with a simple peripheral blood smear may cause to unnecessary processes such as bone marrow biopsy or treatment with G-CSF [1].

In conclusion; in patient with neutropenia for the exclusion of pseudo-neutropenia first procedure must be the evaluation of peripheral blood smear.

\section{NÖTROPENININ NADIR BİR NEDENİ: İLLÜZYON (EDTA`YA BAĞLI PSEUDONÖTROPENI)}

Altmış yaşında erkek hasta. beyin metastazlı squamöz hücreli akciğer $\mathrm{Ca}$ tanıları ile Medikal Onkoloji bölümü tarafından takip edilen hastaya 20.11.2014'de 1.kür Taxol+Cisplatin kemoterapisi ve 01.12.2014 tarihinde de kraniyal RT tedavisi uygulanıyor. 24.12.2014 tarihinde 2.kür KT’sini alan hasta 12.01.2015'de ishal ve oral alım bozukluğu nedeni ile yatırılıyor. Takibi sırasında ani gelişen solunum sıkıntısı olması üzerine 
çekilen PA akciğer grafisinde sol akciğerde pnömotorkas saptanması üzerine göğüs tüpü takılmak üzere yoğun bakıma alınıyor. Göğüs tüpünden püylü mayi gelmesi üzerine kültürlerinde de Escherichia coli ve Enterecoccus faecalis nedeni ile imipenem ve teikoplanin antibiyotik tedavileri başlanıyor. Çekilen toraks CT'de nekrotizan pnömoni saptanarak tedaviye ciprofloksasin ekleniyor. Yatış hemoglobini 10,9 gr/dl, lökosit 5,5x109/L, absolu nötrofil say1s1 3,6x109/L platelet 221x109/L ESH 85/mmh, CRP 17,8 $\mathrm{mg} / \mathrm{dl}$, biyokimyasında patolojik değerleri AST 76IU/L, ALT 47IU/L, LDH 1114U/L, albumin 2,9 g/dl olan hastanın yatışının 2.günü tam kan sayımında lökosit 5,3 x109/L, absolu nötrofil say1s1 0,2 x109/L, kontrol tam kan sayımında lökosit 6,8x109/L mm3, absolu nötrofil sayıs1 $0,3 \times 109 / \mathrm{L}$ gelmesi üzerine Hematoloji konsultasyonu isteniyor. Hastanın bakılan periferik yaymasında aglutinasyonlar oluşturan nötrofil kümeleri izlenmesi üzerine (figure 1) EDTA'ya bağlı pseudo-neutropeni olabileceği düşünelerek sitratlı tüpte tekrar tam kan sayımı yapılarak lökosit sayısı 5,3 x109/L, absolu nötrofil sayıs1 4,6 x109/L saptand1 ve olguya 'EDTA'ya bağlı pseudonötropeni'tanis1 konularak takip tam kan sayımları sitratlı tüpte yapıldı. Hasta yatışının 7.günü sepsis nedeni ile ex oldu

Hastanede yatışı sırasında nötropeni gelişen olgularda ilk akla gelen sebepler ilaç veya enfeksiyonlar olmaktadır. Özellikle hastamızda olduğu gibi mevcut bir malignite ile birlikte nötropeni varsa kemik iliği metastazı da akla gelebilmektedir. Fakat gerçek bir nötropeni yokken, pseudonötropeni aydınlatılmadan etyolojiyi aydınlatmak adına yapılacak kemik iliği veya G-CSF gibi tedaviler gereksiz olmaktadır (1).

Sonuç olarak, nötropeni gelişen olgularda pseudo-nötropeniyi ekarte etmek için, tıpk1 trombositopenili olgulardaki pseudotrombositopeniyi ekarte etmek için yaptığımız gibi yapılması gereken ilk tetkik periferik yaymaolmalidir.

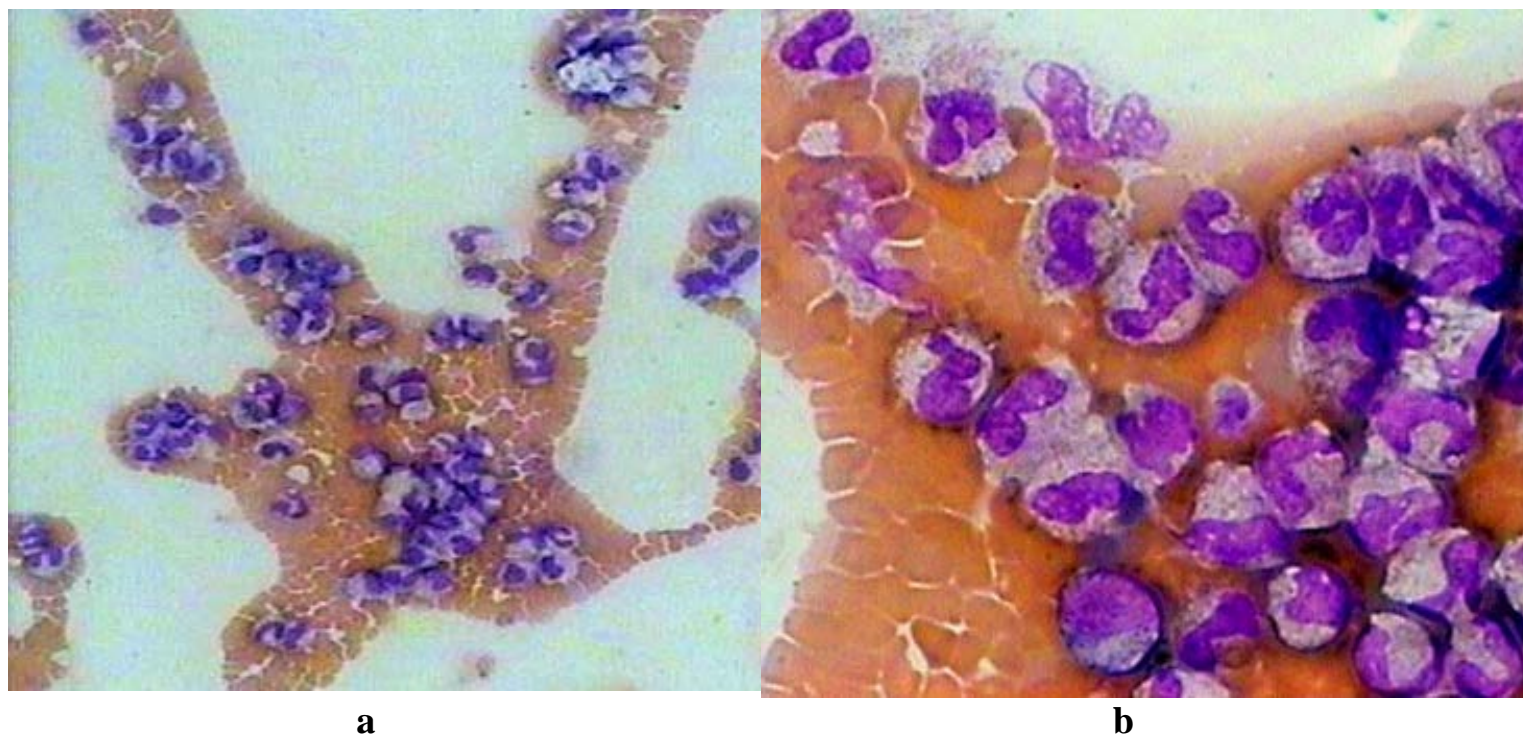

Figure 1. a. Giemsa stained perhipheral smear of EDTA-anticoagulated blood (x10 magnification) b. Giemsa stained perhipheral smear of EDTA-anticoagulated blood (x40 magnification)

\section{REFERENCES}

1. Glasser, L. (2005). Pseudo-neutropenia secondary to leukoagglutination. American journal of hematology, 80(2), 147-147. 